\title{
Pyrethroid Insecticide Effect on Platelet Biomembranes of Rats
}

\author{
Qiuhuan Li ${ }^{1}$, Xiaoyu Liu ${ }^{2}$, Narendra Maddu ${ }^{3}$, Chuanli Zhao ${ }^{1 *}$ \\ ${ }^{1}$ Department of Hematology, Qilu Hospital of Shandong University, Ji-nan, Shandong - 250012, China \\ ${ }^{2}$ School of Public Health, Jilin University, Changchun, Jilin - 130012, China \\ ${ }^{3}$ Department of Biochemistry, Sri Krishnadevaraya University, Ananthapuramu - 515003, Andhra Pradesh, India
}

Received: 11 October 2018

Accepted: 12 January 2019

\begin{abstract}
The effect of Tetramethrin- and prallethrin-based mosquito repellent pyrethroids on rat platelet membranes of cholesterol, phospholipids, lipid peroxidation in platelet membrane was investigated. Rats were chronically exposed to these compounds by continuous inhalation for 8-10 hours a day for 2-3 months, which entered into circulation and counted changes in membranes of platelets. Platelet membrane fluidity was determined by DPH. Pyrene fluorescence anisotropy experiments revealed that tetramethrin and prallethrin exposure to subjects, compared with controls, induced a significant decrease in platelet membrane fluidity as measured by DPH and pyrene. A significant increase in lipid peroxidation was observed in the subjects exposed to both compounds. A significant decrease in the activitiesof platelet membrane-bound enzymes, viz., total ATPase, $\mathrm{Na}^{+} / \mathrm{K}^{+}$-ATPase and $\mathrm{Ca}^{2+}$-dependent ATPase and $\mathrm{Mg}^{2+}$-ATPase was also recorded.
\end{abstract}

Keywords: membrane fluidity, prallethrin, tetramethrin, pyrethroids, lipid peroxidation

\section{Introduction}

Pyrethroids are the most widely used insecticides due to their potential insecticidal activity in India and other countries for protection against mosquitoes and other insects for various domestic and agricultural purposes [1-10]. Pyrethroids are 2250 times more toxic to insects than mammals because insects have increased sodium channel sensitivity, smaller body size, and lower body temperature. Over half of the world's population have been using pyrethroid insecticides, which may account for more than $25 \%$ of the insecticide market of

*e-mail: clzhaoql@163.com

the industrial countries in the 1990s, and their demand/ use is increasing now in these countries [11-12] as the prevalence of mosquitoes and other insects has increased in many parts of the world. Initially, these pyrethroids were thought to be highly toxic to insects and less toxic to humans [13]. Now, pyrethroid-induced neurotoxicity and other toxic effects ranging from whole body tremors to convulsions and death are well documented [12, 14-17]. Very few reports are available so far on the effects of pyrethroids on rats and humans, and now slowly the facts related to their toxicity are coming to light. The fatality with pyrethroids in India has been reported to be 12.5 to $25 \%$ [18]. Prallethrin, a type-I pyrethroid, is among the top few commonly used insecticides having maximal human exposure for prolonged periods as it is used as a chief component of 
mosquito repellents. Tetramethrin and prallethrin are among the most widely used pyrethroid insecticides. Tetramethrin poisoning can be much more frequent due to its easy accessibility as mosquito repellent and/or insecticidal sprays, [19] and often there are reports of pyrethroid poisoning in India [20-21]. However, it is clear that no relevant data on chronic effects exist in open scientific literature related to pyrethroid toxicity in humans and animals $[18,22]$. Since these pyrethroids are used routinely and/or regularly as mosquito repellents and/or through agricultural/gardening sprays exposing people continuously to the inhalation of these compounds for longer durations, their inevitable chronic use aroused a concern among the public now, which formed the basis for the design of the present study. The purpose of the present study is twofold; first, to detect the changes in membrane fluidity of exposed rats to regular use of tetramethrin and prallethrin, and second to understand the role and status of $\mathrm{Na}^{+} / \mathrm{K}^{+}$-ATPase activity and $\mathrm{Ca}^{2+}$-dependent ATPase activity and $\mathrm{Mg}^{2+}$-ATPase in such users of tetramethrin and prallethrin.

\section{Subjects for Study}

The rats were exposed to either mosquito repellent coils or mats, both from markedly available. The coils are composed of $(\mathrm{w} / \mathrm{w}) \quad 0.1 \%$ d-trans tetramethrin, $52.9 \%$ wood flour, $35 \%$ coconut shell powder, $12 \%$ starch, and the mats contained (w/w) $1.6 \%$ d-trans prallethrin and $98.4 \%$ relevant ingredients as indicated by the manufacturers (each group consisting of 8 rats). Release of the pyrethroid insecticide is either by burning the coil or placing the mat in the commercially available electric devices. The rats in the frequent were divided into 3 groups: Group I (control) did not use mosquito repellents; Group II was tetramethrin-exposed rats; Group III was prallethrin-exposed 2-month-old male albino rats of Wistar strain with body weightof 120-140 g, procured from the National Centre for Laboratory Animal Sciences (NCLAS), Hyderabad, A.P., India, and housed in individual cages in an air-conditioned room $\left(25 \pm 1^{\circ} \mathrm{C}\right)$ with light from 7 a.m. to 7 p.m. Hence the present work focused on the chronic effect of pyrethroid-based tetramethrin and prallethrininduced platelet membrane damage/alterations with stress on its mechanism. This study was approved by the institutional ethical committee (JXC20171210) Qilu Hospital of Shandong University, China. Blood samples from overnight fasted subjects were used for the study.

\section{Blood Collection and Plasma Biochemical Determinations}

Plasma glucose was estimated by the method of Trinder [23]. Total cholesterol and triglycerides were measured with enzymatic Allian et al. [24]. HDLcholesterol was determined after precipitation of VLDL and LDL with phosphotungstenic acid and magnesium chloride. VLDL- and LDL-cholesterol concentrations were calculated from the equation; LDL-Cholesterol $=$ total cholesterol-(HDLcholesterol) + VLDLcholesterol), and VLDL cholesterol $=$ Triglycerides $/ 5$. Urea, transaminases, total protein and plasma albumin [25] also were determined spectrophotometrically using commercial kits.

\section{Isolation of Platelets}

Blood was drawn from rats by heart puncture between 7 and 10 a.m. The method of Aster and Jandl [26] was adopted for the isolation of platelets. Ten $\mathrm{ml}$ of blood was collected with acid citrate dextrose (ACD) anticoagulant solution in the ratio of 9:1. The anticoagulated blood was centrifuged at $160 \mathrm{~g}$ for $10 \mathrm{~min}$ to obtain platelet-rich plasma (PRP). This was again centrifuged at $160 \mathrm{~g}$ to remove the red blood cells. The PRP was centrifuged at $300 \mathrm{~g}$ for $5 \mathrm{~min}$ to pellet out platelets. The washing procedure was continued until the suspension was erythrocyte free and the purity was confirmed by microscopic examination. The pellet of platelet was suspended in a platelet storage buffer containing $0.109 \mathrm{M} \mathrm{NaCl}, 4.3 \mathrm{mM} \mathrm{K} \mathrm{HPO}_{4}, 16 \mathrm{mM}$ $\mathrm{Na}_{2} \mathrm{HPO}_{4}, 8.3 \mathrm{mM} \mathrm{NaH} \mathrm{PO}_{4}$ and $5.5 \mathrm{mM}$ glucose, $\mathrm{pH}$ 7.5 , and stored at $4^{\circ} \mathrm{C}$ until further analysis.

\section{Isolation of Platelet Membrane}

Platelet membrane was isolated based on the method adopted by Aneta et al. [27]. An equal volume of platelet suspension and Triton X-100 lysis buffer was taken in microfuge tubes and mixed by inversion. The clarified suspension of platelets was immediately centrifuged at $4^{\circ} \mathrm{C}$ for $2.5 \mathrm{~h}$ at $100000 \mathrm{~g}$. Supernatant was discarded and the translucent platelet membrane pellet was carefully collected from the microfuge tube and used for estimating lipids and other parameters.

\section{Estimating Lipids in Platelet Membrane}

Lipids were extracted from the platelet membrane by the method of Lijiuan et al. [28]. The membrane preparation containing $2 \mathrm{mg}$ of protein $/ \mathrm{ml}$ was mixed with chloroform/methanol mixture $(2: 1, \mathrm{v} / \mathrm{v})$ in the ratio of $1: 9(\mathrm{v} / \mathrm{v})$. The solution was homogenized at low speed and the organic lipid layer was carefully separated and evaporated to dryness in a conical flask. The lipid was dissolved in a known amount of chloroform/methanol mixture. Platelet membrane cholesterol was estimated using ferric acetate/uranyl acetate reagent.

\section{Lipid Peroxidation in Platelets}

The extent of lipid peroxidation was measured by the formation of malondialdehyde (MDA) by the method of Negre-Salvayre et al. [29]. One $\mathrm{ml}$ of the platelet membrane was taken in a test tube to which $2 \mathrm{ml}$ of reagent $(15 \% \mathrm{w} / \mathrm{v}$ TCA, $0.375 \% \mathrm{w} / \mathrm{v}$ TBA 
and $0.25 \mathrm{~N} \mathrm{HCl}$ ) was added and kept in boiling water bath for 15 minutes and the contents were allowed to cool and then centrifuged at $1000 \mathrm{~g}$ for 10 minutes. The supernatant was transferred into a separate test tube and the absorbance of the sample was read at $535 \mathrm{~nm}$ by a UV/Visible spectrophotometer against the reagent blank assuming the molar extinction coefficient to be $1.56 \times 10^{5}$.

\section{Assay of Platelet Membrane-Bound Enzymes}

The activity of total ATPase was determined by the method of Evans [30] using ATP as the substrate in the presence of $\mathrm{Na}^{+}, \mathrm{K}^{+}, \mathrm{Mg}^{2+}$, and $\mathrm{Ca}^{2+}$ ions. $\mathrm{Na}^{+}, \mathrm{K}^{+}-$ ATPase activity was measured according to the method of Bonting [31] in the presence of $\mathrm{Na}^{+}$and $\mathrm{K}^{+}$ions. The level of $\mathrm{Mg}^{2+}$-dependent ATPase was determined by the method of Ohnishi et al. [32], and $\mathrm{Ca}^{2+}$-dependent ATPase activities were quantified by the method of Hjerton and Pan [33] using ATP as substrate in the presence of $\mathrm{Mg}^{2+}$ and $\mathrm{Ca}^{2+}$ ions, respectively. In all ATPases assays, the activity was expressed in terms of nanomoles of phosphorus liberated/minute per $1 \mathrm{X} 10^{5}$ platelets. a)

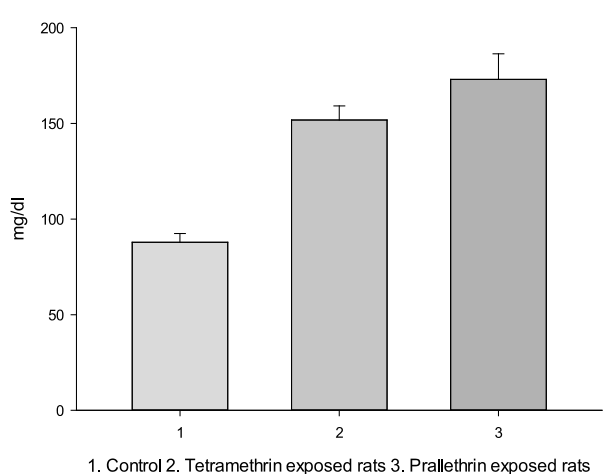

c)

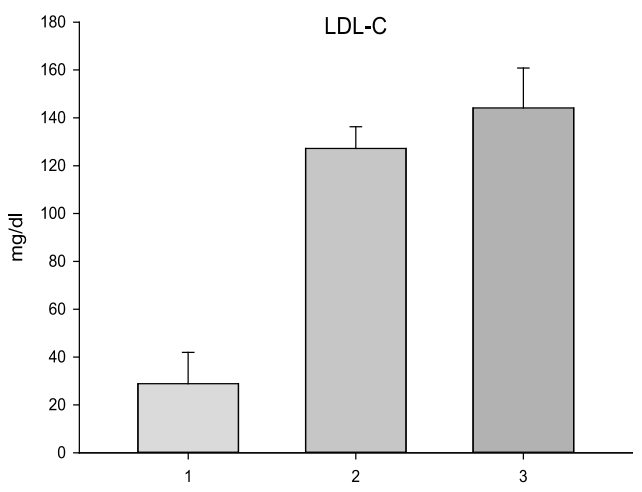

1. Control 2. Tetramethrin exposed rats 3 . Prallethrin exposed rats

e)

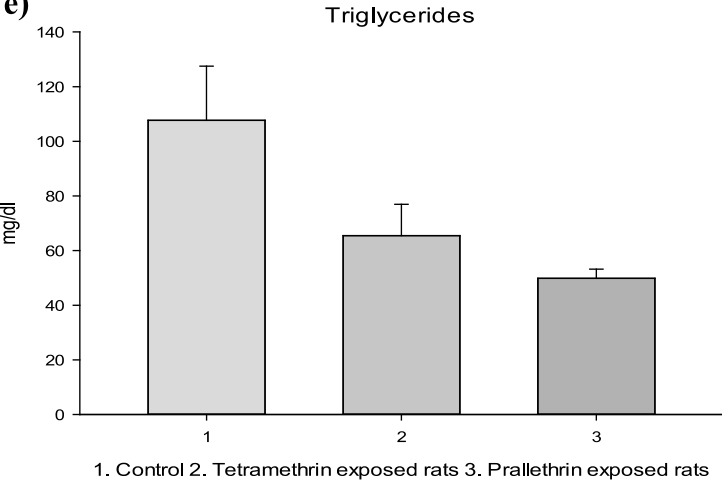

b)

HDL-C

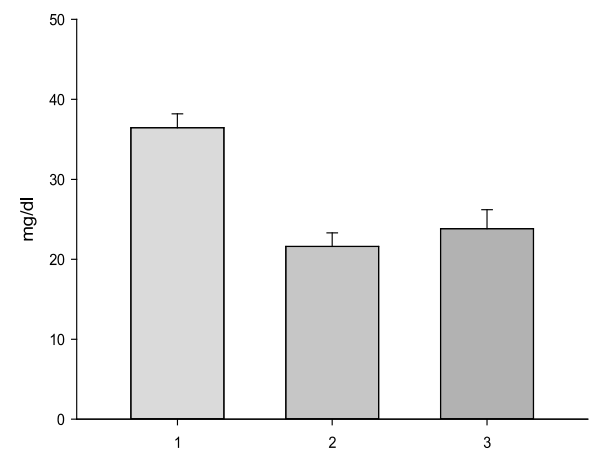

1. Control 2. Tetramethrin exposed rats 3 . Prallethrin exposed rats

d)

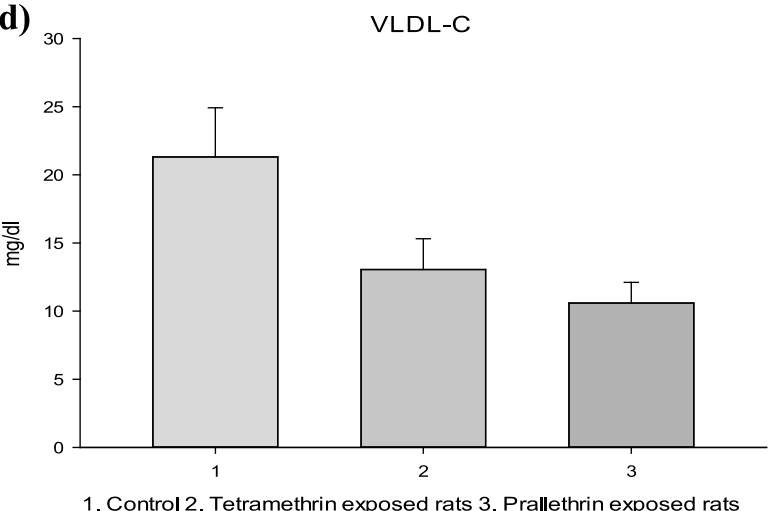

ig. 1(a-e). Pyrethroid-induced lipid profile alterations of control and exposed rats.

Values are shown as Mean \pm Standard Deviation $(n=8)$. Different superscript letters in the same line indicate statistically significant difference for $P<0.05$. NS $=$ Not Significant. 


\section{Fluorescence Measurement}

Fluorescence measurements on platelet membranes and lipid extracts were performed on a spectrofluorometer. Steady-state fluorescence anisotropy (r) measurements for DPH and pyrene were obtained using the excitation and emission wavelengths at 360 and $430 \mathrm{~nm}$, respectively. The degree of fluorescence anisotropy $(r)$ was calculated according to Shinitzky and Barenholz [34] from the equation:

$$
r=\left(I||-I \_g\right)
$$
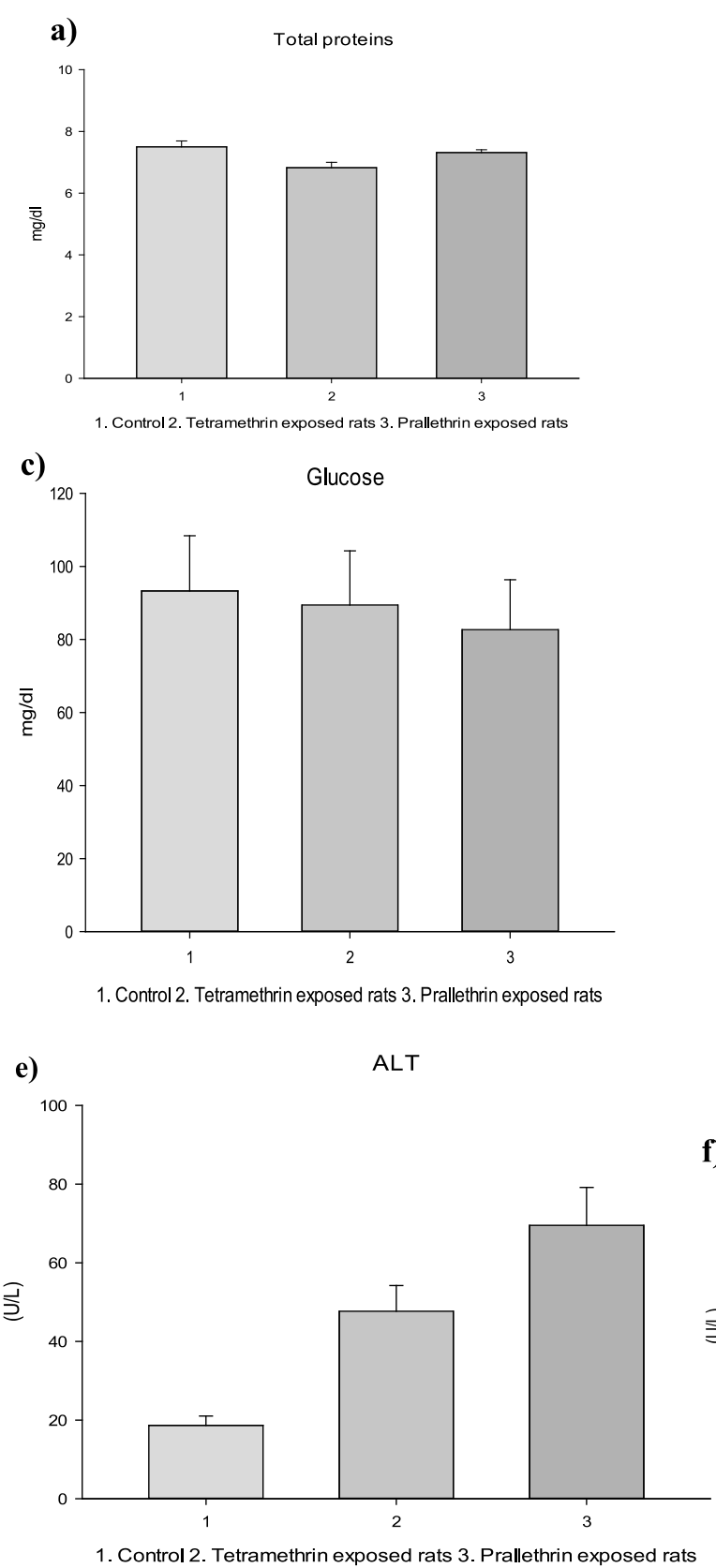

$$
(I \|+2 I G G)
$$

...where $G$ is an instrumental correction factor, and are, respectively,and the intensities were measured with the polarization plane parallel and perpendicular to that of the exciting beam. The final protein concentration in the assay was $0.4 \mathrm{mg} / \mathrm{ml}$, while the probe concentration was $10^{-6} \mathrm{M}$. Fluorescence measurements performed on lipid extracts were normalized to the same content of proteins $(0.4 \mathrm{mg} / \mathrm{ml})$. Samples were suspended in 10 $\mathrm{mM}$ Tris $\mathrm{pH} 7.4$ and the measurements were performed at $25^{\circ} \mathrm{C}$.

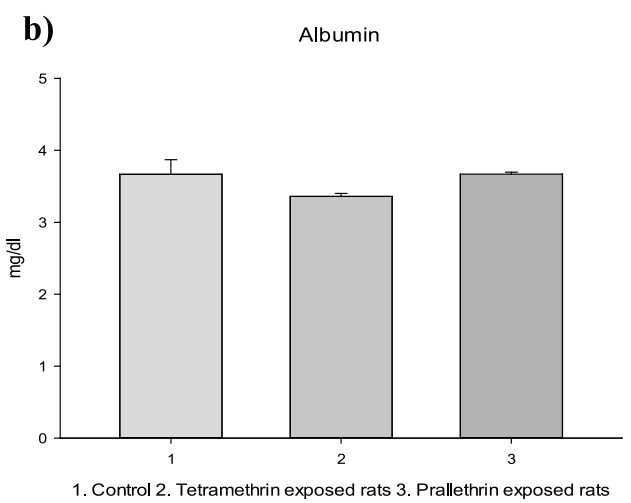

d)

Urea
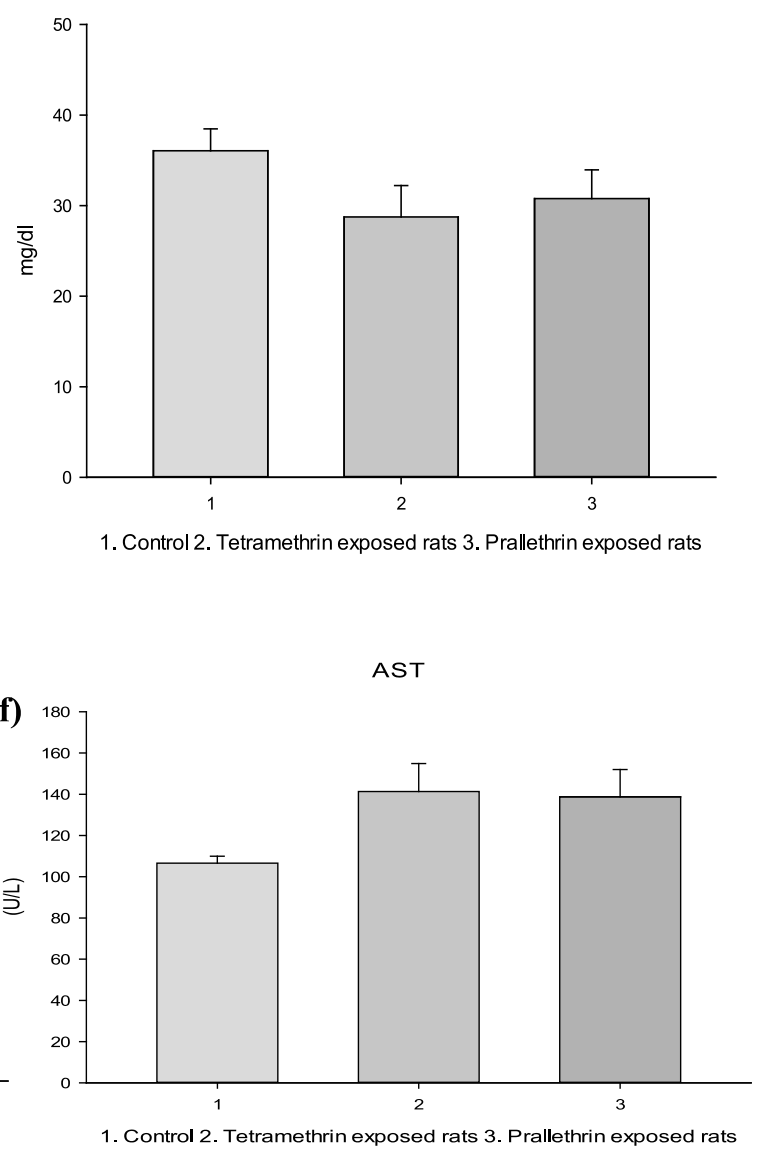

Fig. 2(a-f). Pyrethroid-induced alterations of control and exposed rat plasma profile.

Values are shown as Mean \pm Standard Deviation $(n=8)$. Different superscript letters in the same line indicate statistically significant difference for $P<0.05$. NS $=$ Not Significant. 


\section{Statistical Analysis}

The results of the study are expressed as mean \pm SD. Statistical analysis was performed using Duncan's multiple range (DMR) test. The significance was tested at $(P \leq 0.05)$.

\section{Results}

The results obtained in this study are clear by revealing a significant increase in platelet membrane cholesterol (C) and a decrease in phospholipid (P) content with no significant change in the protein contents in platelet membranes of tetramethrin and prallethrinexposed subjects group II and group III when compared to controls group I. The increase in consequent C:P ratio in tetramethrin and prallethrin-exposed subjects was observed when compared with control. Furthermore, a significant increase in platelet membrane lipid peroxidation in the experimental subjects is obvious from this study (Table 1). Data furnished in Table 2 indicate decreased levels of platelet membranebound enzymes total ATPase, $\mathrm{Na}^{+}, \mathrm{K}^{+}$-ATPase, $\mathrm{Mg}^{2+}$-ATPase, and $\mathrm{Ca}^{2+}$-ATPase in platelets of tetramethrin- and prallethrin-exposed subjects group II and group III when compared to controls group I. Plasma cholesterol and LDL-C levels increased significantly with no change triglycerides, HDL-C, VLDL-C (Fig. 1a-e). Glucose levels decreased in rats exposed to both while total proteins and albumin levels increased slightly when compared to control, and no change in ALT, AST, or urea levels were observed (Fig. 2a-f). Hemoglobin levels in pyrethroid-inhaled rats decreased significantly, whereas $\mathrm{RBC}, \mathrm{WBC}$, and platelet counts were altered intetramethrin- and prallethrinexposed rats (Fig. 3a-d). Modifications in platelet fatty acid chain length (fatty acid composition 16.0, 20.4 significantly) also was observed in (Fig. 4a-c). Data presented (Fig. 5a, b) showed that use of pyrethroids led to a significant decrease in platelet membrane fluidity in rats exposed to both.

\section{Discussion}

In the present study,the platelet membrane of tetramethrin- and prallethrin-exposed subjects showed an increase in cholesterol and decrease in phospholipid contents when compared to control, with no change in platelet membrane protein moiety, which suggested alterations in membrane organization affecting lipidlipid, lipid-protein, and protein-protein interactions in the membrane, and with an increase in $\mathrm{C} / \mathrm{P}$ ratio and a significant increase in lipid peroxidation (Table 1). Liver is the central organ involved in metabolism of
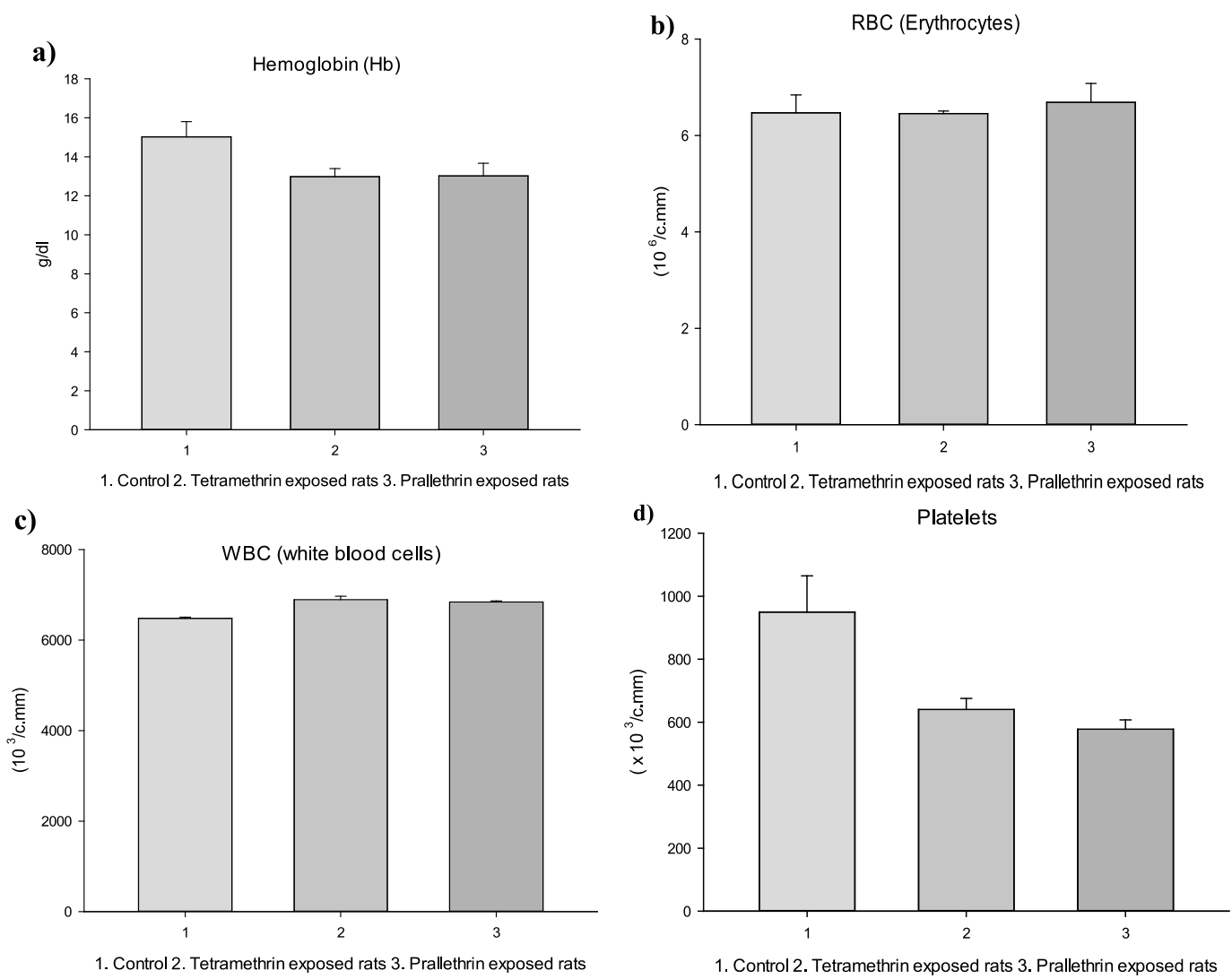

Fig. 3(a-d). Pyrethroid-induced changes of $\mathrm{Hb}, \mathrm{RBC}, \mathrm{WBC}$, and platelets of exposed rats

Values are shown as Mean \pm Standard Deviation $(n=8)$. Different superscript letters in the same line indicate statistically significant difference for $P<0.05$. NS $=$ Not Significant. 
cholesterol, phospholipids, triglyceride and lipoproteins. The functional impairments of liver would result in the reduced capacity to synthesize many important biomolecules, including lipids. Results from the present study observed increased levels of cholesterol and decreased levels of phospholipids. Platelet dysfunction in liver diseases is associated with an abnormality in lipid composition [35]. Our study showed an increase in the cholesterol/phospholipids ratio, leading to a decrease in membrane fluidity. Increased $\mathrm{c} / \mathrm{p}$ ratio in tetramethrin- and prallethrin-based pyrethroidinduced platelet membrane indicates decreased fluidity, thereby influencing viscoelastic properties of the membrane,which is in agreement with other reports [36-38]. This result was further confirmed by the fluorescence anisotropic studies using pyrene, which showed a decrease in translational mobility of pyrene due to increased intra membrane micro viscosity,

a)
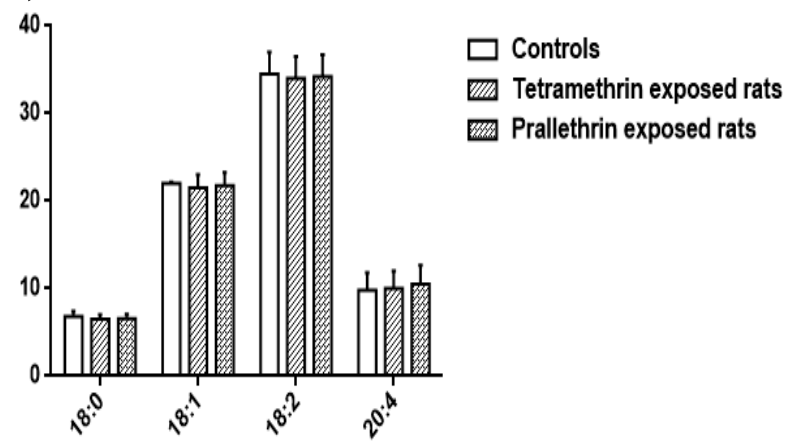

b)
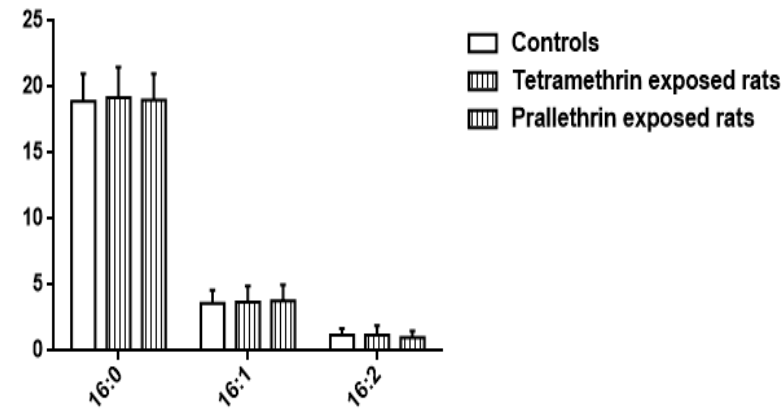

c)

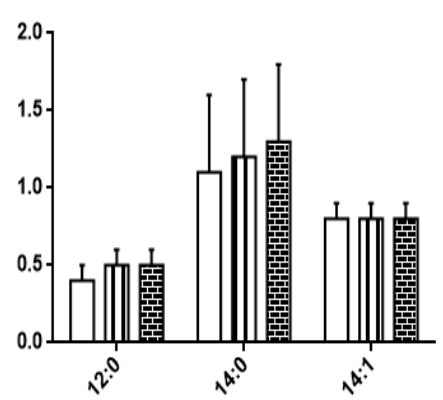

$\square$ Controls

III Tetramethrin exposed rats 国 Prallethrin exposed rats

Fig. 4(a-c). Effect of mosquito repellent pyrethroid exposure on fatty acid composition of platelet membrane.

Values are shown as Mean \pm Standard Deviation $(n=8)$. Different superscript letters in the same line indicate statistically significant difference for $P<0.05$. NS $=$ Not Significant. which is indicative of the decreased platelet membrane fluidity. This finding contradicts the results reported by Hrelia et al. [39]. This decrease in membrane fluidity might affect receptor functions by changing the lateral mobility or clustering of receptors in their vertical orientation [40]. Phospholipids have been reported to influence membrane fluidity. Our study suggests that the increase in the cholesterol/phospholipid ratio might have affected membrane fluidity. If membrane fluidity decreases, the secretary function of the platelet will be severely affected. The procoagulants will not be secreted at a normal level, thereby affecting aggregation. Fig. (1a-1e) shows a significant increase in serum cholesterol in pyrethroid groups and a significant reduction of its HDL fraction compared to the control group. LDL-cholesterol no difference was found in relation to triglycerides and VLDL-cholesterol, as compared to control animals. This apparently unexpected result could be explained by the activity of lipoprotein
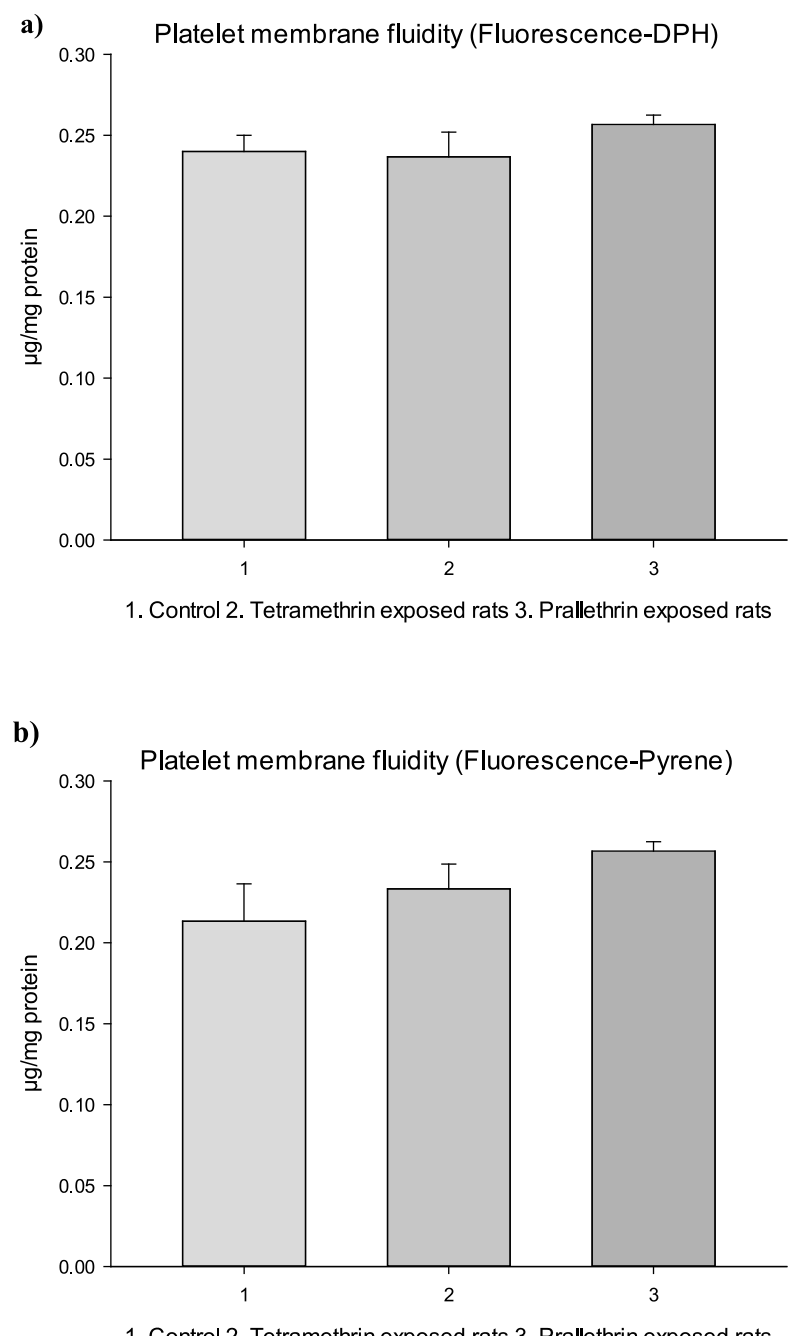

Fig. 5(a-b). Effect of mosquito repellent pyrethroid exposure on platelet membrane fluidity.

Values are shown as Mean \pm Standard Deviation $(\mathrm{n}=8)$. Different superscript letters in the same line indicate statistically significant difference for $P<0.05$. NS $=$ Not Significant. 
Table 1. Pyrethroid effect on platelet parameters.

\begin{tabular}{|c|c|c|c|}
\hline \multirow{2}{*}{ Parameter } & \multicolumn{3}{|c|}{ Groups } \\
\cline { 2 - 4 } & Controls & $\begin{array}{c}\text { Tetramethrin exposed } \\
\text { Rats }\end{array}$ & $\begin{array}{c}\text { Prallethrin exposed } \\
\text { Rats }\end{array}$ \\
\hline $\begin{array}{c}\text { Cholesterol } \\
\left(\mathrm{ng} / 110^{5} \text { platelets }\right)\end{array}$ & $0.174 \pm 0.009 \mathrm{a}$ & $0.212 \pm 0.009 \mathrm{~b}$ & $0.244 \pm 0.006 \mathrm{~b}$ \\
\hline $\begin{array}{c}\text { Phospholipid } \\
\left(\mathrm{ng} / 110^{5} \text { platelets }\right)\end{array}$ & $0.206 \pm 0.009 \mathrm{a}$ & $0.164 \pm 0.006 \mathrm{~b}$ & $0.158 \pm 0.005 \mathrm{~b}$ \\
\hline Platelets Cholesterol/Phospholipid ratio & $0.84 \mathrm{a}$ & $1.29 \mathrm{~b}$ & $1.54 \mathrm{~b}$ \\
\hline Lipid Peroxidation (MDA formed ( $\mu$ moles x $10^{5}$ platelets) & $0.62 \pm 0.04$ & $1.20 \pm 0.05$ & $1.18 \pm 0.05$ \\
\hline
\end{tabular}

Values are expressed as mean \pm SEM, in each column, followed by the same letter are not significantly different $(P \leq 0.05)$ from each other according to Duncan's Multiple Range (DMR) test, $\mathrm{n}=8$.

lipase. Lipid metabolism has also been assessed besides other biochemical parametersthus, aiming at a picture of the hepatic function of the animals since the liver is the major organ responsible for maintenance of homeostasis related to lipid metabolism. Fig. 2(a-f) shows a significant decrease in serum albumin, glucose and total proteins in exposed subjects, but no change in ALT, AST and urea was observed in the two groups when compared to control. This finding corroborated how the high caloric value of the diet might have impaired the absorption of proteins and other nutrients. Decreased platelet counts and haemoglobin concentration in experimental rats exposed to (tetramethrin and prallethrin) significantly exposed slight increases in WBC counts. In RBC count significant increases in prallethrin rats saw no change in tetramethin rats compared to control (Fig. 3a-d). Fatty acid composition was altered significantly in subjects exposed to both (fatty acid chain 16.0, 20.4 significantly) Fig. 4(a-c). Data presented in Fig. 5(a-5b) shows the on-influence anisotropy (r) values in control and tetramethrin- and prallethrinexposed subjects platelet membranes showed a decrease in membrane fluidity in group II and group III experimental subjects when compared to control group $\mathrm{I}$ in both DPH and pyrene-using probes. Pyrethroids are fat-soluble pesticides, and therefore they accumulate in fat deposits in the body [41]. The highest concentration of fat in the body is in the brain due to the lipid-based myelin sheaths surrounding every nerve cell [41]. Generally, the fluidity of biomembranes is responsible for their functional integrity, which is largely determined by the levels of protein and cholesterol/phospholipid ratio. A significant alteration in the level of lipids in platelet membrane would contribute to the secretory functions and thereby on the defective adhesive and aggregation properties. The myelin sheath serves as an insulator and conductor, protecting the nerve and giving the neural impulses speed and direction. All types of pesticides can degrade the myelin sheath [41]. If demyelinization occurs, nerve impulses are either slowed (sometimes to the point of halting), or they misfire because there is no conductor to give them direction. The observed increase in lipid peroxidation in tetramethrin- and prallethrin-exposed subjects when compared to controls corroboratest he reports of others [42-43]. Data presented in Table 2 reveal the inhibition of ATPases, the enzymes associated with the platelet membrane, like ATPases and nucleotidases, are essential for the membrane-related functions like adhesion, aggregation and secretion of granules. $\mathrm{Na}^{+}$, $\mathrm{K}^{+}$-ATPase belongs to a family of ATPases which are present in virtually all mammalian cell membranes. Other members of this family include enzymes dependent upon magnesium $\left(\mathrm{Mg}^{2+}\right.$-ATPase $)$ and calcium (Ca ${ }^{2+}$-ATPase). Because $\mathrm{Na}^{+}, \mathrm{K}^{+}$-ATPase transports $\mathrm{Na}^{+}$ions extracellulerly and $\mathrm{K}^{+}$-ions intracellularly,

Table 2. Effect of mosquito repellent use on platelet ATPases.

\begin{tabular}{|c|c|c|c|}
\hline \multirow{2}{*}{ Parameter } & \multicolumn{3}{|c|}{ Groups } \\
\hline & Controls & Tetramethrin exposed Rats & Prallethrin exposed Rats \\
\hline Total ATP ase & $24.31 \pm 1.10 \mathrm{a}$ & $15.40 \pm 1.80 \mathrm{~b}$ & $16.10 \pm 1.60 \mathrm{~b}$ \\
\hline $\mathrm{Na}^{+}, \mathrm{K}^{+}$-ATP ase & $18.22 \pm 1.08 \mathrm{a}$ & $13.50 \pm 1.28 \mathrm{~b}$ & $14.60 \pm 0.78 \mathrm{~b}$ \\
\hline $\mathrm{Mg}^{2+}$-ATP ase & $18.40 \pm 1.20 \mathrm{a}$ & $14.15 \pm 0.74 b$ & $15.64 \pm 1.02 b$ \\
\hline $\mathrm{Ca}^{2+}$-ATP ase & $14.68 \pm 1.28 \mathrm{a}$ & $10.28 \pm 0.97 b$ & $11.44 \pm 1.34 \mathrm{~b}$ \\
\hline \multicolumn{4}{|c|}{$\begin{array}{l}\text { Activities are expressed as nmoles of phosphorus liberated/min per } 1 \text { X } 10^{5} \text { platelets. Values are expressed as mean } \pm \text { SEM in each } \\
\text { column, followed by the same letter are not significantly different }(P \leq 0.05) \text { from each other according to Duncan's Multiple Range } \\
(\mathrm{DMR}) \text { test, } \mathrm{n}=8 \text {. }\end{array}$} \\
\hline
\end{tabular}


it plays an important role in maintaining the level of membrane polarization [44]. Consequently, modulation of $\mathrm{Na}^{+}, \mathrm{K}^{+}$-ATPase activity may lead to alterations in the function of various cell types, including peripheral blood mononuclear cells. In our study, it is observed that there is a significant reduction in the activity of $\mathrm{Na}^{+}, \mathrm{K}^{+}$-ATPase, which might result in reduced cation exchange through the membrane and thereby its reduced energy-dependent secretory functions. Biochemical characterization of the calcium ATPases isolated from human platelet intracellular and plasma membranes has been reported [45]. This enzyme catalyses $\mathrm{Ca}^{2+}$ dependent exchange of hydride ions to calcium ions which influence the rate of signal transduction is essential for the timely release of secretory granules and the formation of actomyosin complex in the platelet membrane during adhesion. So, the observed low level of calcium ATPase activity would have also influenced the defective platelet activities such as adhesion, aggregation and secretion.

\section{Conclusions}

An increase in platelet membrane cholesterol and decrease in phospholipids, with no change in proteins, were observed in exposed subjects, which appears to be an adaptive biochemical change in platelet membrane. Decreased membrane fluidity of platelet membrane, increased lipid peroxidation and a significant decrease in platelet membrane-bound enzymes were recorded. Further studies are needed to correlate the toxic effects of prolonged use of tetramethrin and prallethrin on rat platelet membrane.

\section{Acknowledgements}

Authors thank Retd. Prof. P.B.B.N Charyulu, Department of Microbiology, Sri Krishnadevaraya University, Ananthapuramu, for his valuable suggestions.

\section{Conflict of Interest}

The authors declare no conflict of interest

\section{References}

1. MOSQUERA ORTEGA M.E., ROMERO D.M., PATO A.M., SOSA-HOLT C.S., RIDOLFI A., VILLAAMIL LEPORI E., WOLANSKY M.J. Relationship between exposure, body burden and target tissue concentration after oral administration of a low-dose mixture of pyrethroid insecticides in young adult rats. Toxicology. 409, 53, 2018.

2. BARDULLAS U., SOSA-HOLT C.S., PATO A.M., NEMIROVSKY S.I., WOLANSKY M.J. Evidence for effects on thermoregulation after acute oral exposure to type I and type II pyrethroids in infant rats. Neurotoxicol Teratol. 52 (Pt A), 1, 2015.

3. BOWMAN N.M., AKIALIS K., CAVE G., BARRERA R., APPERSON C.S., MESHNICK S.R. Pyrethroid insecticides maintain repellent effect on knock-down resistant populations of Aedes aegypti mosquitoes. PLoS One. 13, e0196410. 2018.

4. BHASKAR E.M., MOORTHY S., GANESHWALA G., ABRAHAM G. Cardiac conduction disturbance due to prallethrin (pyrethroid) poisoning. J Med Toxicol. 6, 27, 2010.

5. MOSSA A.T., REFAIE A.A., RAMADAN A., BOUAJILA J. Amelioration of prallethrin-induced oxidative stress and hepatotoxicity in rat by the administration of Origanum majorana essential oil. Biomed Res Int. 859085. 2013.

6. SAIM H., MAHESHWARI T.P. Pyrethroid based repellen inhalation induced changes in physical activity in albino rats after chronic exposure. International J Scientific Res Pub. 3 (3), 1, 2013

7. MADHUBABU G., YENUGU S. Effect of continuous inhalation of allethrin-based mosquito coil smoke in the male reproductive tract of rats. Inhal Toxicol. 24 (3), 143, 2012.

8. 8. RAMOS-CHAVEZ L.A., SORDO M., CALDERONARANDA E., CASTANEDA-SAUCEDO E., OSTROSKYWEGMAN P., MORENO-GODINEZ M.E. A permethrin/ allethrin mixture induces genotoxicity and cytotoxicity in human peripheral blood lymphocytes. J Toxicol Environ Health A. 78 (1), 7, 2015.

9. LI H., LYDY M.J., YOU J. Pyrethroids in indoor air during application of various mosquito repellents: Occurrence, dissipation and potential exposure risk. Chemosphere. 144, 2427, 2016.

10. NA H.G., KIM Y.D., CHOI Y.S., BAE C.H., SONG S.Y. Allethrin and prallethrin stimulates MUC5AC expression through oxidative stress in human airway epithelial cells. Biochem Biophys Res Commun. 503 (1), 316, 2018.

11. WALKER J.T., SUCKING D.M., WEARING C.H. Past, Present, and Future of Integrated Control of Apple Pests: The New Zealand Experience. Annu Rev Entomol. 62, 231, 2017.

12. SODERLUND D.M. Molecular mechanisms of pyrethroid insecticide neurotoxicity: recent advances. Arch Toxicol. 86, 165, 2012.

13. BABINA K., DOLLARD M., PILOTTO L., EDWARDS J.W. Environmental exposure to organophosphorus and pyrethroid pesticides in South Australian preschool children: a cross sectional study. Environ Int. 48, 109, 2012.

14. CLARK J.M., SYMINGTON S.B. Advances in the mode of action of pyrethroids. Top Curr Chem. 314, 49, 2012.

15. GAMMON D.W., LEGGETT M.F., CLARK J.M. Pyrethroid mode(s) of action in the context of Food Quality Protection Act (FQPA) regulation. J Agric Food Chem. 59, 2773, 2011.

16. STARR J.M., SCOLLON E.J., HUGHES M.F., ROSS D.G., GRAHAM S.E., CROFTON K.M., WOLANSKY M.J., DEVITO M.J., TOMERO-VELEZ R. Environmentally relevant mixtures in cumulative assessments: an acute study of toxicokinetics and effects on motor activity in rats exposed to a mixture of pyrethroids. Toxicol Sci. 130, 309, 2012.

17. TSUJI R., YAMADA T., KAWAMURA S. Mammal toxicology of synthetic pyrethroids. Top Curr Chem. 314, 83, 2012. 
18. KAMBLE V.S. Study of chronic treatment of mosquito repellent liquid inhalation on biochemical constituents of rats. International Journal of Applied Biology and Pharmaceutical Technology. 3, 189, 2012.

19. EK C.J., DZIEGIELEWSKA K.M., HABGOOD M.D., SAUNDERS N.R. Barriers in the developing brain and Neurotoxicology. Neurotoxicology. 33, 586, 2012.

20. RAMESH P., MAHASWI S., SURENDER K. Childhood Accidental Poisoning In South India. IOSR Journal of Dental and Medical Sciences. 15, 77, 2016.

21. SATISH K.V., SHIVAKUMAR P., MANDAR RAMACHANDRA S. Sociodemographic profile of paediatric poisoning cases in Bangalore, India. Indian Journal of Forensic and Community Medicine. 2, 225, 2015.

22. SAILlENFAIT A.M., NDIAYE D., SABATE J.P. Pyrethroids: exposure and health effects-an update. Int $\mathrm{J}$ Hyg Environ Health. 218, 281, 2015.

23. TRINDER P. Determination of glucose by glucose oxide method. Ann Clin Biochem. 6, 24, 1969.

24. ALLIAN C.C., POON L.S., CHAN C.S.G., RICHMAND W., FU P. Enzymatic determination of total serum cholesterol. Clin Chem. 20, 470, 1974.

25. WOOTTON I.D.P. Microanalysis in Medical Biochemistry. Churchill Livinggastone. 156, 158, 1974.

26. ASTER R.H., JANDL J.H. Platelet sequestration in man. I Methods J Clin Invest. 43, 843, 1964.

27. WRZYSZCZ A, URBANIAK J, SAPA A, WOŹNIAK M. An efficient method for isolation of representative and contamination-free population of blood platelets for proteomic studies. Platelets. 28, 43, 2016.

28. LIJIUAN D.U., YOUNG M., XIN L.I., PANLI S.H.I., ZHIQI H.U. A Novel and Convenient Method for the Preparation and Activation of PRP without Any Additives: Temperature Controlled PRP. Biomed Res Int. 1761865. 2018.

29. NEGRE-SALVAYRE A., AUGE N., AYALA V., et al. Pathological aspects of lipid peroxidation. Free Radical Research. 44, 1125, 2010.

30. EVANS D.J. Jr. Membrane adenosine triphosphatase of Escherishia coli: activation by calcium ion and inhibition by monovalent cations. J Bacteriol. 100, 914, 1969.

31. BONTING S.L. In Membranes and ion transport (Bitter E, ed) 1, 257, Elsevier, Amsterdam, 1970.

32. OHNISHI T., SUZUKI T., SUZUKI Y., OZAWA K. A comparative study of plasma membrane $\mathrm{Mg}^{2+}$-ATPase activities in normal, regenerating and malignant cells. Biochim Biophy Acta. 684, 67, 1982.

33. HJERTON S., PAN H. Purification and Characterization of two forms of a low affinity $\mathrm{Ca}^{2+}$-ATPase from erythrocyte membranes. Biochim Biophy Acta. 728, 281, 1983.
34. SHINITZKY M., BARENHOLZ T. Fluidity parameters of lipid regions determined by fluorescence polarization. Biochem Biophys Acta. 515 (4), 367, 1978.

35. PERSONAL COMMUNICATION. Interview with Bev Pagan. Ap 28, 2002.

36. MATURU P., VARADACHARYULU N. Adaptive changes in fatty acid profile of erythrocyte membrane in relation to plasma and red cell metabolic changes in chronic alcoholic men. Hum Exp Toxicol. 31, 652, 2012.

37. SARADAMMA B., DAMODARA REDDY V., PADMAVATHI P., PARAMAHAMSA M., PAVAN KUMAR P., VARADACHARYULU N. Association between alcohol-induced erythrocyte membrane alterations and hemolysis in chronic alcoholics. J Clin Biochem Nutr. 60, 63, 2017.

38. MATURU P., VADDI D.R., PANNURU P., NALLANCHAKRAVATHULA V. Alterations in erythrocyte membrane fluidity and $\mathrm{Na}^{+} / \mathrm{K}^{+}$-ATPase activity in chronic alcoholics. Mol Cell Biochem. 339, 35, 2010.

39. WEIJIERS R.N. Lipid composition of cell membranes and its relevance in type 2 diabetes mellitus. Curr Diabetes Rev. 8, 390, 2012.

40. HODI A., SOUlA A.C., GUILlaumE B. Membrane microdomains emergence through non-homogeneous diffusion. BMC Biophys. 5, 6, 2012.

41. PUBLIC HEALTH STATEMENT PYRETHRINS and PYRETHROIDS. Agency for Toxic Substances and Disease Registry. 2003.

42. HERMANN P.B., PIANOVSKI M.A., HENNEBERG R., NASCIMENTO A.J., LEONART M.S. Erythrocyte oxidative stress markers in children with sickle cell disease. J Pediatr (Rio J). 92, 394, 2016.

43. ILYASOVA D., FONTANA L., BHAPKAR M., PIEPER C.F., SPASOJEVIC I., REDMAN L.M., DAS S.K., HUFFMAN K.M., KRAUS W.E. CALERIE Study Investigators. Effects of 2 years of caloric restriction on oxidative status assessed by urinary F2-isoprostanes: The CALERIE 2 randomized clinical trial. Aging Cell. 17, e12719. 2018.

44. MANGIALAVORI I., MONTES M.R., ROSSI R.C., FEDOSOVA N.U., ROSSI J.P. Dynamic lipid-protein stoichiometry on E1 and E2 conformations of the $\mathrm{Na}^{+} / \mathrm{K}^{+}$ -ATPase. FEBS Lett. 585, 1153, 2011.

45. FAFULA R.V., IEFREMOVA U.P., LYCHKOVSKA N.E., VOROBETS' Z.D. Kinetic properties of $\mathrm{Na}^{+}, \mathrm{K}^{+}$activated, $\mathrm{Mg}^{2+}$-dependent ATP-hydrolysis of blood lymphocytes in patients with rheumatoid arthritis and ankylosing spondyloarthritis. Ukr Biokhim Zh (1999). 84, 44, 2012. 
